\title{
Design and creation of control board for drying equipment based on development of a soft self-tuning PID controller
}

\author{
Thiết kế chế tạo mach điều khiển cho thiết bị sấy mẫu trên cơ sở phát triển bộ \\ điều khiển PID mềm tư chỉnh linh hoạt
}

Research article

Ngo, Thanh Binh*

Faculty of Electrical and Electronic Engineering, University of Transport and Communications, No.3, Lang Thuong, Dong Da, Ha Noi, Vietnam

\begin{abstract}
This article introduces a versatile control board design that can be used in many drying systems using direct heat transfer solutions in combination with static tray distribution based on development of a flexible self-tuning PID controller. The product is applied for a small oven drying solid waste samples or plant materials for further analysis of some parameters. The control board is built based on the Arduino embedded system using a flexible soft PID (Proportional-Integral-Derivative) controller that can automatically change its gains according to the required temperature thresholds to best meet the setpoint of temperatures. The system has a small steady-state error (SSE), fast response to the setpoints and keep stable with temperature deviation when reaching the required threshold around $\pm 0.5{ }^{\circ} \mathrm{C}$. In addition, the controller board can operate in a variety of modes, including direct temperature operation, pre-set operation, and switching mode.
\end{abstract}

Bài báo này giới thiệu một thiết kế mạch điều khiển đa năng có thể áp dụng trong nhiều hệ thống sấy sử dụng các giải pháp truyền nhiệt trực tiếp kết hợp phân phối khi kiểu khay tĩnh trên co sở phát triển bộ điều khiển PID mềm tư chỉnh linh hoạt. Sản phẩm được ứng dụng cho một mô hình lò nhỏ sấy mấu chất thải rắn hoặc mẫu thực vật phục vụ các nghiên cứu phân tích thành phần một số chất. Mạch điều khiển được chế tạo trên nền tảng hệ thống nhúng Arduino sư dụng bộ điều khiển PID mềm linh hoạt, có khả năng tự động thay đổi tham số theo nguỡng nhiệt yêu cầu để đáp ưng nhiệt độ tốt nhất so với nguõng nhiệt độ đặt. Hệ thống có độ quá điều chỉnh nhỏ, nhanh đáp úng tới các ngữơng đặt và giữ ổn định với sai lệch nhiệt độ khi đạt ngương yêu cầu trong khoảng $\pm 1^{0} \mathrm{C}$. Ngoài ra, bộ điều khiển còn có thể hoạt động theo nhiều chế độ khác nhau, bao gồm hoạt động theo chế độ đặt nhiệt độ trục tiếp, hoạt động theo chu trình đặt trước, và chuyển chế độ hoàn toàn tụ động.

Keywords: Drying equipment, soft self-tuning PID, plant materials

\section{Introduction}

Drying is the process of using heat to reduce the moisture content of a material based on the partial pressure of water vapor on the surface of the material and the surrounding environment. Its purpose is to inhibit the changes due to the presence of water as the growth of microorganisms and the catalysis of enzymes to prolong the time of preserving plant samples. For research related to processing and analysis of solid waste samples or plant materials, drying is one of the most commonly used methods. Plant samples are required drying at $40-50^{\circ} \mathrm{C}$ before cutting to analyze some parameters such as $\mathrm{N}, \mathrm{P}, \mathrm{K}, \mathrm{Ca}, \mathrm{Mg}, \mathrm{Fe}, \mathrm{S}$, and trace elements (TCVN 8551:2010). Solid waste samples are needed to be dryed at $110-150^{\circ} \mathrm{C}$ before incineration at $300^{\circ} \mathrm{C}$ in 1 hour and then at $550^{\circ} \mathrm{C}$ to analyse some inorganic compositions such as $\mathrm{Al}, \mathrm{Cu}, \mathrm{Cr}, \mathrm{Fe}, \mathrm{Mg}, \mathrm{Mn}$, $\mathrm{Ni}, \ldots$ (TCVN 9458:2012).

In some case, before putting the material into the drying process, some chemical or physical treatments may need to be applied to improve the energy efficiency of the drying process. In addition, for each type of material, it is necessary to dry at different temperature ranges over suitable time periods, in which the deviation of the ther- 
mal threshold must always be below the specified level. These elements create a drying cycle, which must be strictly followed and monitored closely. In these cases, PID controllers have been widely employed in real processes.

Nowadays, research and application of new technologies to improve drying equipment are very interested. There are several new scientific studies on self-tuning PID controller, such as: PID gains calculated directly (Yoichiro Ashida et al., 2017), tuning of fractional PID (Ayadi Guefrachi et al., 2017). There are also some self-tuning PID solutions used combination of methods, such as Genetic algorithms (Mihailo P. et al., 2013), fuzzy logic (Y.I. Kudinova et al., 2017), and robust (Emre Sariyildiz et al., 2015). However, all of them aren't operating in preset cycle or multimode, that are required for drying research materials before analysis. In Vietnam, there are some drying researches using popular technology, mainly applied to large areas for drying agricultural products and aquatic products, not good enough to dry the samples for analysis. On a small scale, there are specialized drying cabinets. However, most of these drying cabinets usually focus only on the manufacturing technology and structure of the oven. There is always a quite big steady state error in proportional control, and their real temperature values are oscillation around setpoint with quite big error, commonly more than $2 \%$ of setpoint. This may adversely affect the quality of the sample, especially for samples that are required to be accurately temperature-dried. In addition, they have no automatic cycle control mode, and most of them require manual operation by hand. Moreover, the temperature data of these machines are also not recorded automatically to the database at the station for the monitoring process. Therefore, design and manufacture of multi-purpose control circuits which can be run by PID program with small oscillation around setpoint for specimen drying equipment to process raw materials for further analysis is necessary.

A flexible self-tuning PID controller is the most suitable controller for controlling drying ovens. Depending on the material types, the weight of samples to be dried and the required quality of final product, we will calculate the corresponding parameters, write to the software and upload to the controller. For different objects, we need to recalculate the appropriate parameters and re-upload into the controller which basically does not need to change the designed hardware. The smarter way is we calculate and upload several parameters and use switching mode in PID controller for each rang of temperature of each material suitably.

\section{PID review and development}

\subsection{PID review}

The PID controller is the most popular controlling tool for a wide variety of industrial process controller units. In temperature control, we have voltage, called PV (Process Variable), corresponding to the current state of our system, which is calculated from real temperature. The PV is the value we pass to PID control loop to tell it about the state of the system. We also have a SP (setpoint) voltage, corresponding to the state we wish our PV to reach. Basically, we want PID loop to drive our system so that SP and PV are equal, or different values are as small as good. That means we have a control voltage, $u$, which corresponds to the instantaneous voltage value we are using to drive our system towards its SP voltage. The control voltage can be considered as what is actually sent to the system to guide it what we want it reaches. It's analogous to a relay status that our control loop is controlling.

In general, the control function can be expressed mathematically as follows (Yoichiro Ashida et al., 2017):

$$
u(t)=M V(t)=K_{P} e(t)+K_{I} \int_{0}^{t} e(\tau) d \tau+K_{D} \frac{d}{d t} e(t)(1)
$$

Where:

○ $K p, K i, K d$ denote the coefficients for the proportional, integral, and derivative gains respectively;

- $e(t)$ denotes the feedback error, calculated by deference of setpoint and input values, or: $e(t)=r(t)-$ $y(t)$

- $\quad t$ is the time or instantaneous time (the present);

- $\tau$ is the variable of integration (takes on values from time 0 to the present $t$ ).

In this study, as a model of tuning of fractional complex order PID controller (Ayadi Guefrachi et al., 2017), we firstly consider an architecture of a closed-loop system modelled by its transfer function $G(s)$, controlled by a controller presented by its transfer function $C(s)$ shown as in figure 1:

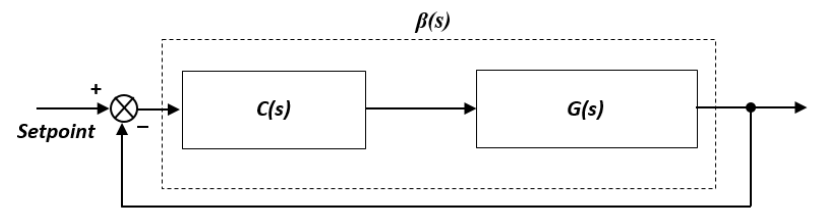

Figure 1. Unity-feedback closed-loop process

Where: $\beta(s)$ denotes the complex order to define the openloop function.

\subsection{Development of PID tuning parameters}

There are many studies related to calculate and tuning of PID parameters. Basically, we can use several methods, such as: Ziegler-Nicholos; Tyreus Luyben; Cohen-Coon Parameters; Astrom-Hagglund; Yoichiro Ashida (Yoichiro Ashida et al., 2017).

The Ziegler-Nicholos (ZN) rule is the first acceptable criterion produced for solving the tuning problem, which would have been performed using some heuristics involving trial and error procedures. Similar to the ZieglerNichols method, a set of tuning parameters of CohenCoon Parameters method were developed to yield a closed-loop response with a decay ratio of $1 / 4$. It may be argued that the biggest problem with these parameters is that slight variations in process parameters can cause an unstable sealing system. Astrom-Hagglund method is relay method, which temporarily operates the process using bang-bang control and measures the resultant oscil- 
lations. The output is switched between two values of the control variable. As long as the process variable is below the setpoint, the control output is assigned to the higher value. As soon as it rises above the setpoint, the control output is assign to the lower value. In approximate calculation, the output waveform is nearly square, spending equal time above and below the setpoint. The period and amplitude of the resultant oscillations are measured and used to calculate the ultimate gains and period of time, then applied to the Ziegler-Nichols method. That means to reach the best way for this application of drying equipment, we develop a combination of manual method and Astrom-Hagglund relay method.

The software architecture consists of multimode as shown in Figure 2, in which manual mode operating by pushing buttons directly, and switching mode operating by time following preset values depended on drying materials.

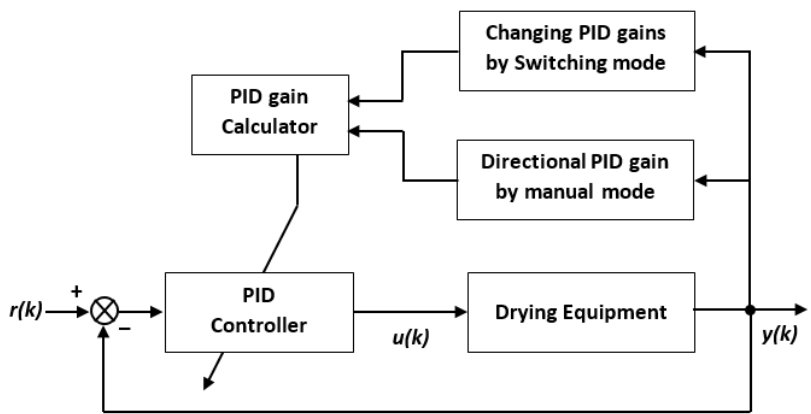

Figure 2. Block diagram of the proposed method

In fact, $K p, K i$ and $K d$ are all non-negative, named as Tuning Parameters (or "Tunings"). Adjusting these values will change the way that the output reachs setpoint rapidly, slowly, or god-awfully depending on the values of good or bad $K p, K i$, and $K d$. So, what are the "right" tuning values to use? There isn't only one right answer. The values of PID gains that can work for one application perfectly may not work well for another, just as the driving style that works for a bus will not work for a race car. With each new application we will need to try several tuning values until we find a set that gives us the best acceptable results.

\section{Design of drying equipment based on soft self-tuning PID}

\subsection{Structure of system device on sample drying oven}

The devices of our system have been designed and created from consumer equipment such as Arduino platform, LCD DM1602, temperature sensor DS18B20, wire heating resistor $\mathrm{MH} 01,2-\mathrm{Channel} 5 \mathrm{~V}$ relay. In addition, we istall two fans to circulate hot air in the small experimental oven, one external thermometer used to extra check temperature inside that oven, and some other supplemental devices. Power supply for control board includes both 5.0 VDC and 3.3 VDC, and for wire heating is 220 VAC controlled by relay. The devices are all assembled on the experimental oven as shown in Figure 3.
The software for experimental drying oven is built on Arduino IDE, in which we develop Arduino-PID-Library V1 (Brett Beauregard, 2018), with a self-tuning PID controller running in multimode described in Figure 2.

Control board is designed, created and operated as shown in Figure 4, and the result of this test can be shown in figure 5 . In this test, we run it in mode 3 of manual mode to check oven. For operating in other modes, we can change easily by pushing buttons on control board.

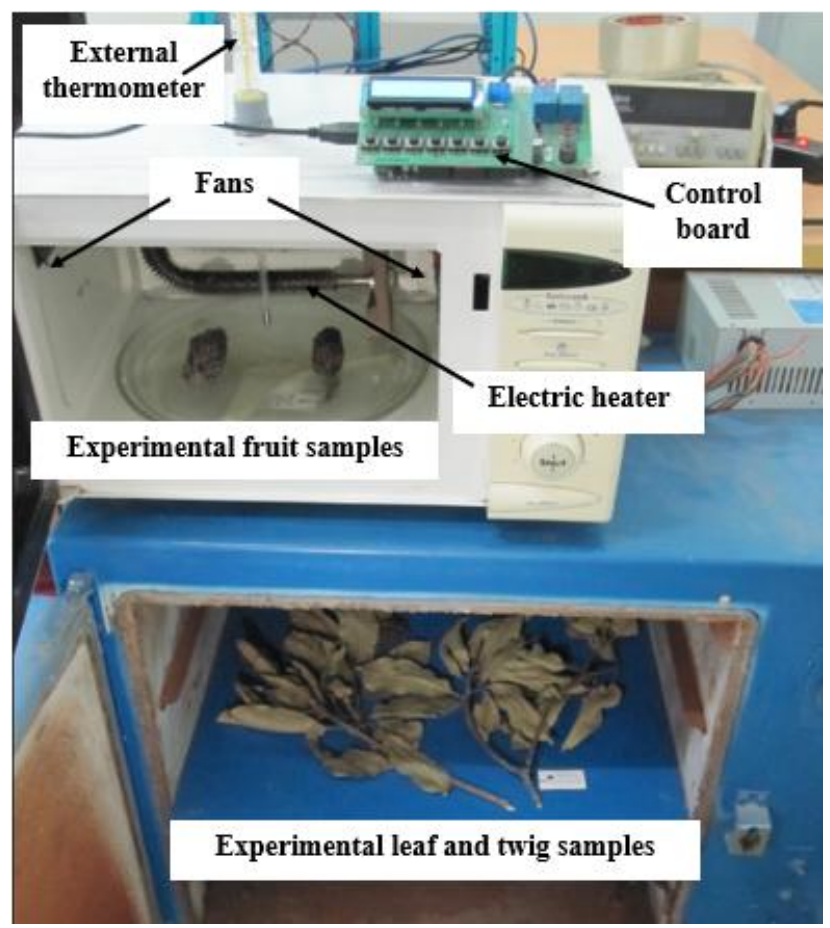

Figure 3. Real devices installed in the oven

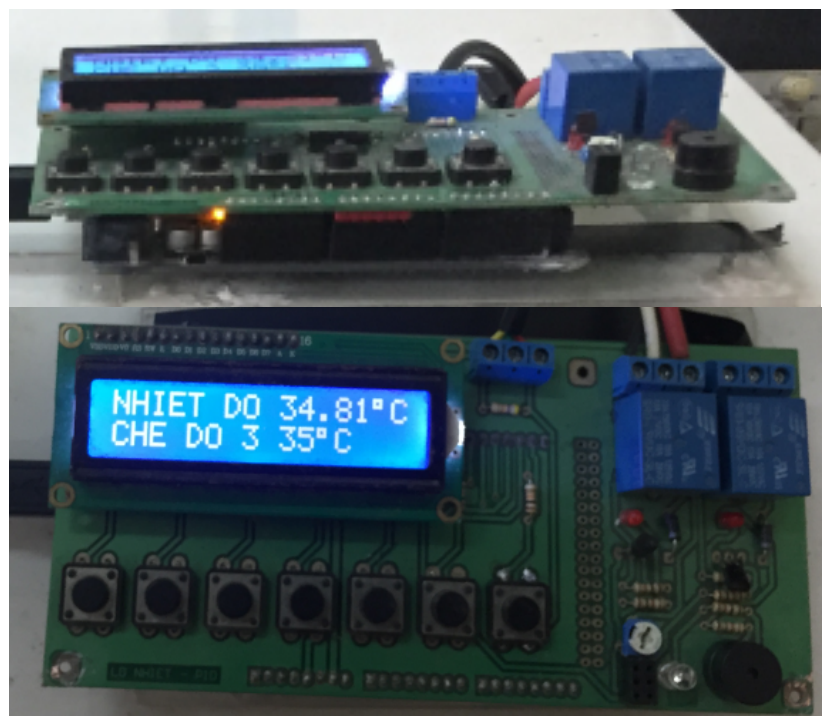

Figure 4. Control board of experimental drying oven

Figure 4 showed that the board operatesin mode 3 (CHE DO 3), setpoint is $35{ }^{\circ} \mathrm{C}$, and temperature (NHIET DO) is $34.81{ }^{\circ} \mathrm{C}$, that means error is $0.19^{\circ} \mathrm{C}$. For this test, we set big $K p$ to reach temperature rapidly and have big proportional error as maximum of approximate of $2.5^{\circ} \mathrm{C}$. After two times over fluctuate far from setpoint of this level, temperature back to reach to setpoint level and stable with 
small error of $\pm 0.5^{0} \mathrm{C}$. All of temperature data are described on graphs and logged in database on management and monitoring PC at the station automatically. During the time of one hour, errors of temperature are always stable in range of $\pm 0.5^{0} \mathrm{C}$.

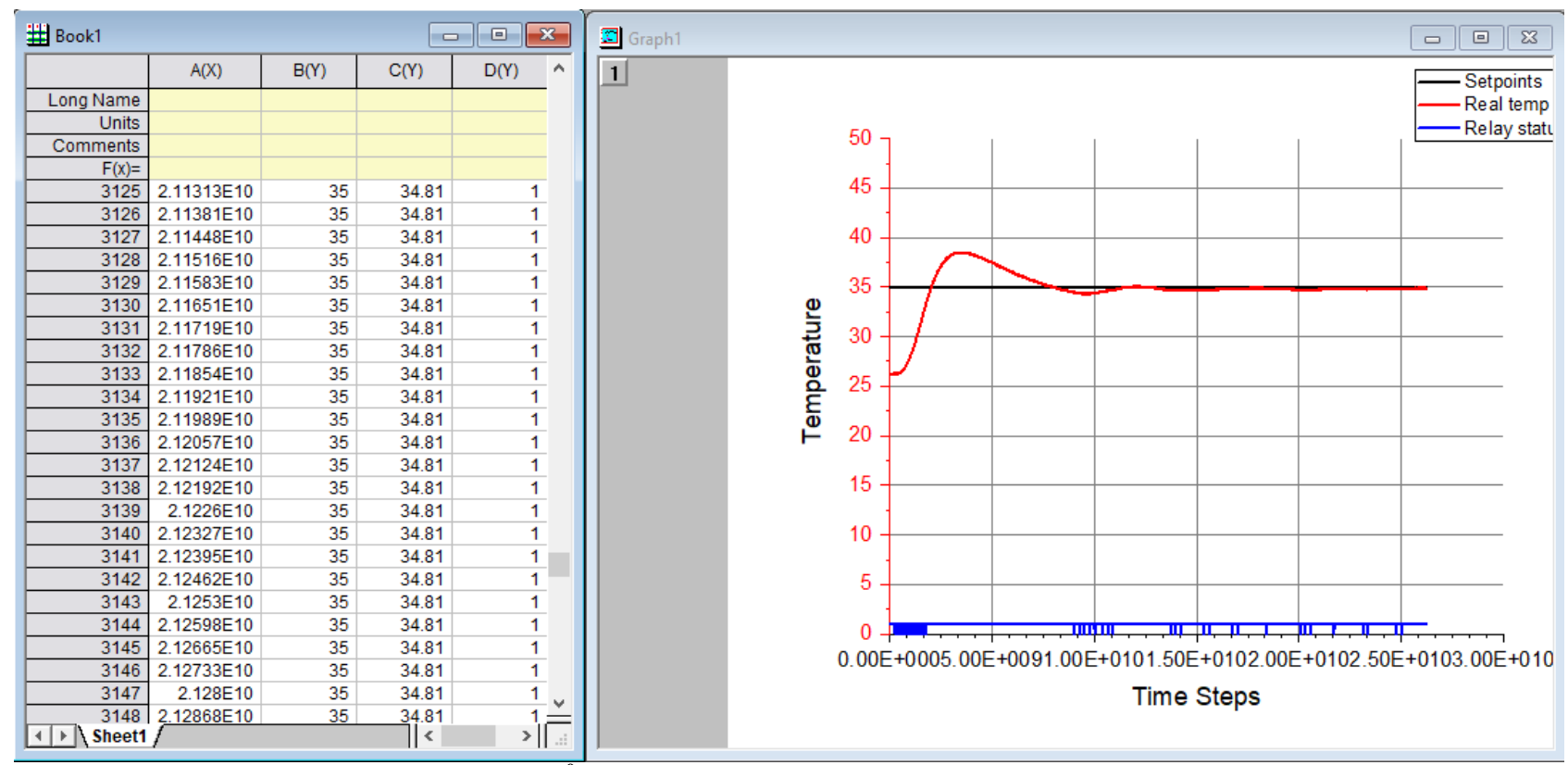

Figure 5. The result of testing level of $35^{\circ} \mathrm{C}$

Testing of automatic changing levels of $30^{\circ} \mathrm{C}$ and $35^{\circ} \mathrm{C}$ in switching modes, we have good results as shown in figure 6. After preset time of running with its gain of $30^{\circ} \mathrm{C}$, PID can change its gains automatically, suitable for a new temperature level of $35^{\circ} \mathrm{C}$. Number of over fluctuation far from setpoint according to each level is just one time, maximum under $2^{0} \mathrm{C}$, and errors of both levels always in rang of $\pm 0.5^{\circ} \mathrm{C}$. We can see values of temperature on the example frame on the left of Figure 6 that all of data recorded on database are always in range of $0.5^{\circ} \mathrm{C}$.

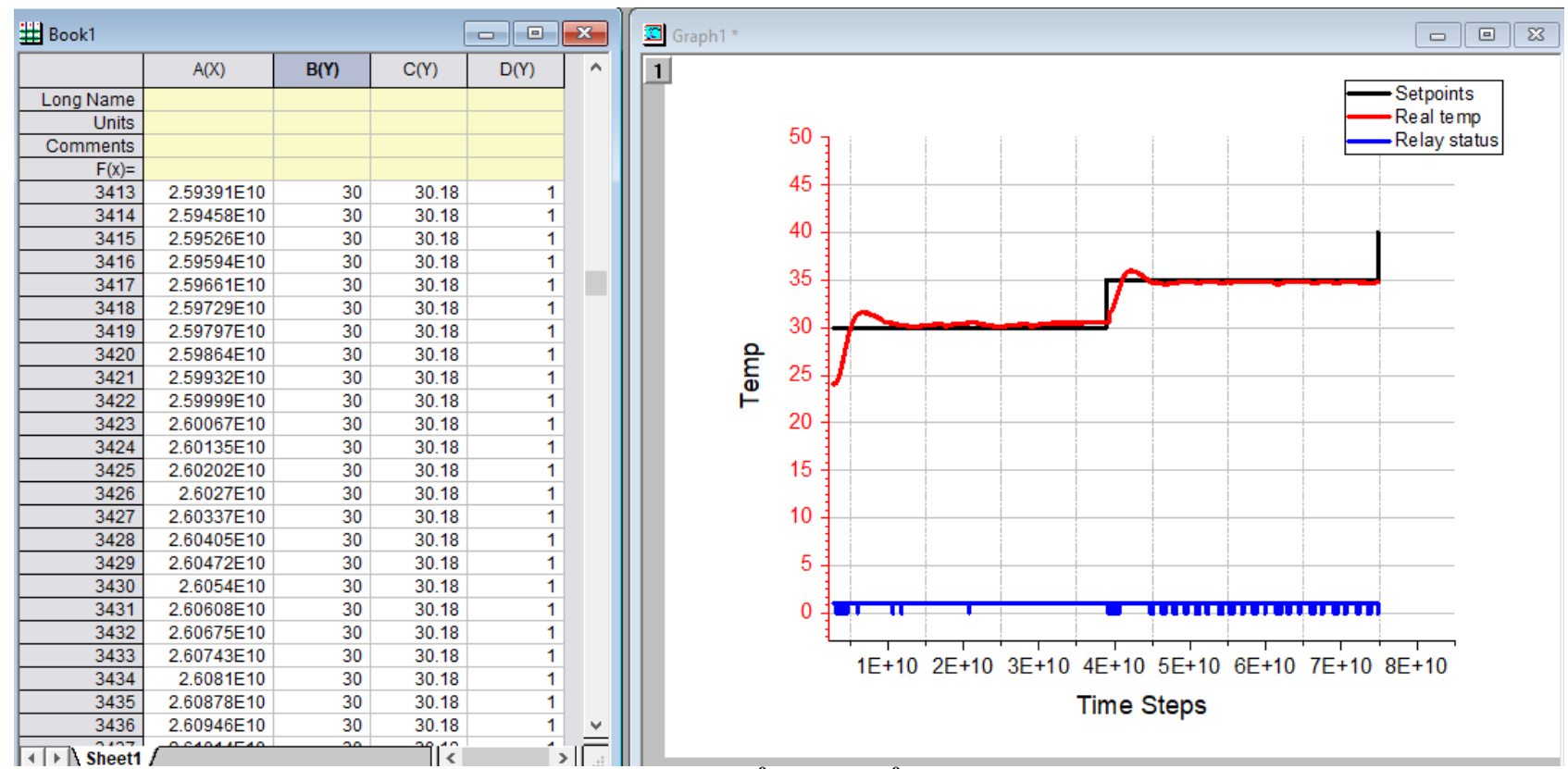

Figure 6. The result of automatic changing levels of $30^{\circ} \mathrm{C}$ and $35^{\circ} \mathrm{C}$ in switching mode

\subsection{Experiment and results of drying of drug materials}

There are results of experiment of drying of leaf and stem specimens of Magnolia chevalieri for drug materials (Raja, 2017), (Choomuenwai, 2014). In this experiment, we turn on system in switching mode and operate following the preset time cycle suitable for drying plant samples.
The temperatures are set on six levels including $25^{\circ} \mathrm{C}$, $30^{\circ} \mathrm{C}, 35^{\circ} \mathrm{C}, 40^{\circ} \mathrm{C}, 45^{\circ} \mathrm{C}$ and $50^{\circ} \mathrm{C}$. The time for each testing level can set after by pushing buttons on the control board depended on material, in this experiment for small oven is 60 minutes. PID gains are chosen including: $\mathrm{Kp}=0.5, \mathrm{Ki}=0, \mathrm{Kd}=5$ for level of $25^{\circ} \mathrm{C} ; \mathrm{Kp}=1.5, \mathrm{Ki}=0.1$, $\mathrm{Kd}=3$ for level of $30^{\circ} \mathrm{C} ; \mathrm{Kp}=1.9, \mathrm{Ki}=0.01, \mathrm{Kd}=1$ for level of $35^{\circ} \mathrm{C} ; \mathrm{Kp}=1.5, \mathrm{Ki}=0.01, \mathrm{Kd}=1$ for level of $40^{\circ} \mathrm{C}$; $\mathrm{Kp}=1.6, \mathrm{Ki}=0.2, \mathrm{Kd}=3$ for level of $45^{\circ} \mathrm{C}$; and $\mathrm{Kp}=2.8$; 
$\mathrm{Ki}=0.2 ; \mathrm{Kd}=1$ for level of $50^{\circ} \mathrm{C}$. Note that all of these gains are chosen for this experiment drying oven. For other ovens, they could be changed depending on power of wire heating resistor, volume and material of each one.

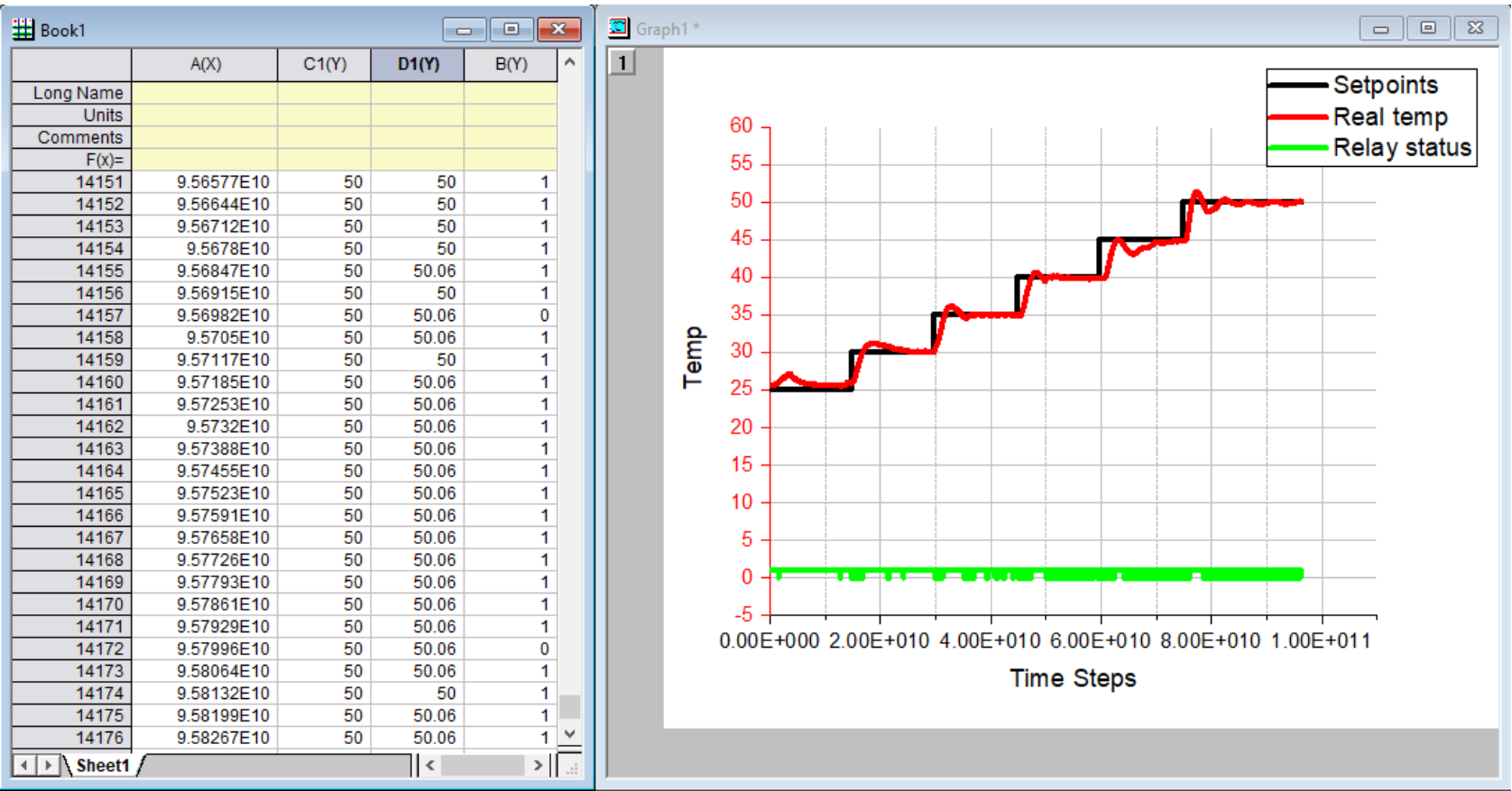

Figure 7. The result of automatic changing level of one full sample experiment drying equipment

The results of automatic changing of six levels in switching mode above are described in figure 7. As shown on graph, and also written on database on PC logged automatically at the station, we can see that after some fluctuations according to each level, maximum under $2^{0} \mathrm{C}$, and as shown on the left of Figure 7 all errors of temperature in six levels recorded on database are always stable in range of $\pm 0.5^{0} \mathrm{C}$.

\section{Conclusion}

In this article, gains of self-tuning PID are calculated by testing signals during the identification test based on manual and Astrom-Hagglund methods. After that, they can be written in software of a self-tuning PID controller, which can operate for changing temperature in switching mode automatically. By applying the approach, not only the closed-loop system can be identified accurately but also the control performance is improved during the tests by using multimode flexibly, including normal mode which writes PID gains directly by pressing buttons, and switching mode which changes suitable gains of PID for each level automatically. In all modes, we have good results that temperature is always stable in range of \pm $0.5^{0} \mathrm{C}$.

Experimental samples are well automatically processed by using the drying oven that its control board operates based on development of a self-tuning PID controller. Labour is not required to keep a watch over the oven to switch the mode of temperature for drying samples demanding multimode of different temperature steps. For different kinds of specimens, we can change and install suitable gains and time for each level depended on input material characteristics and required qualiy of final product. This board can also be installed on other drying ovens or other devices with other suitable gains for each one calculated before without any change of hardware design. This design can be easily developed for other purposes such as creating a thermal environment for MEMS INS and other sensors testing, furnace manufacturing, waste incineration, ect. This is an effective direction, capable of developing wide application, meet for many kinds of materials and bring high economic efficiency, especially in developing countries likeVietnam.

Acknowledgements: This article was funded by the Ministry of Education and Training (MoET) under grant number B2016-GHA-02.

\section{References}

[1] Yoichiro Ashida, Shin Wakitani, Toru Yamamoto. 2017. Design of an Implicit Self-tuning PID Controller Based on the Generalized Output. International Federation of Automatic Control IFAC 50-1 (2017) pp. 13946--13951

[2] Ayadi Guefrachi, Slaheddine Najar, Messaoud Amairi, Mohamed Aoun. 2017. Tuning of Fractional Complex Order PID Controller. IFAC 2017, 50-1, pp. $14563-14568$

[3] Mihailo P. Lazarevic, Srecko A. Batalov, Tihomir S. Latinovic. 2013. Fractional PID Controller Tuned by Genetic Algorithms for a Three DOF's Robot System Driven by DC motors. 2013 IFAC, pp. 385--390

[4] Y.I. Kudinova, V.A. Kolesnikova, F.F. Pashchenkob, A.F. Pashchenkob, L. Papicc. 2017. Optimization of fuzzy PID controller's parameters. International Symposium «Intelligent Systems», INTELS'16, pp. 618--622 
[5] Emre Sariyildiz, Haoyong Yu and Kouhei Ohnishi. 2015. A Practical Tuning Method for the Robust PID Controller with Velocity Feed-Back. Machines 2015, 3, pp. 208-222

[6] Brett Beauregard. Arduino PID Library - Version 1. http://playground.arduino.cc/Code/PIDLibrary. Last accessed 14 May 2018

[7] Dr. S. Raja. 2017. Investigation of hepatoprotective and antioxidant activities of indian medicinal plants. Research Project of Institute of Pharmacy Gitam
University.

[8] Vanida Choomuenwai. 2014. Antimalarial natural products from terrestrial macrofungi. $\mathrm{PhD}$ thesis of Griffith University.

[9] TCVN 8551:2010 (2010) Vietnam Standard 8551:2010: Plants - Method for sampling and preparing sample.

[10] TCVN 9458:2012 (2012) Vietnam Standard 9458:2012: Standard practice for dissolution of solid waste by lithium metaborate fusion. 